\title{
Еректильна дисфункція
}

\section{як предиктор ризику розвитку}

серцево-судинних захворювань

у чоловіків із цүкровим

діабетом 2-го типу
М.Д. Тронько,

Є.В. Лучицький,

В.Є. Лучицький,

Л.К. Соколова,

\section{Г.А. Зубкова,}

В.М. Рибальченко,

\section{I.I. Складанна,}

Ю.Б. Бельчіна

ДУ «Інститут ендокринології та обміну речовин ім. В.П. Комісаренка НАМН України»

Резюме. В огляді проаналізовано роль еректильної дисфункції (ЕД) у чоловіків, хворих на цукровий діабет 2-го типу, як одного з ранніх маркерів розвитку серцево-судинних захворювань (СС3). Висвітлено сучасні погляди на порушення функції ендотелію як спільного субстрату, що становить підґрунтя розвитку як ЕД, так і ССЗ.

Ключові слова: еректильна дисфункція, серцево-судинні захворювання, чоловік, цукровий діабет 2-го типу.

Еректильна дисфункція (ЕД) є поширеним захворюванням у чоловіків і негативно впливає на якість їх життя та міжособистісне благополуччя в сім'ї. У тривалих дослідженнях встановлено, що поширеність ЕД серед чоловіків становить 32-80\% залежно від віку [1]. ЕД насамперед розвивається в чоловіків старших вікових груп, для яких, за даними деяких досліджень, може бути маркером підвищеного ризику смерті. Для цієї популяції чоловіків підтримка статевого життя є важливим аспектом якості жит-

* Адреса для листування (Correspondence): ДУ «Інститут ендокринології та обміну речовин ім. В.П. Комісаренка НАМН України», вул. Вишгородська, 69, м. Київ, 04114 , Україна. E-mail: zdovado@ukr.net

( ) М.Д. Тронько, Є.В. Лучицький, В.Є. Лучицький, Л.К. Соколова, Г.А. Зубкова, B.М. Рибальченко, І.І. Складанна, Ю.Б. Бельчіна тя. У більшості випадків ЕД маніфестує у віці 40-50 років, після 60 років вірогідно зростають її частота та тяжкість [2]. У нещодавно проведених дослідженнях встановлено, що частота ЕД серед чоловіків віком 45-59 років і понад 60 років була в 6,5 і 7 разів вищою порівняно з такою серед осіб віком до 45 років [3]. Також за результатами обстеження 1705 чоловіків старших вікових груп (понад 70 років), проведеного 20052007 роками та 2014 року ( $=958)$, поширеність ЕД становила 64\% і 80\% [4], що свідчить про зростання частоти ЕД.

Одним із перших досліджень поширеності ЕД у загальній популяції чоловіків було Масачусет- 
ське дослідження старіння чоловіків (MMAS), за даними якого частота ЕД становила $52 \%$ серед чоловіків 40-79 років, причому помірна ЕД спостерігалася у 25,2\% випадків, мінімальна у $17,2 \%$ і тяжка - у 9,6\% спостережень [5]. ЕД було діагностовано у $28 \%$ чоловіків із цукровим діабетом (ЦД), у 9\% - із серцево-судинними захворюваннями (СС3) і в 15\% - із гіпертонічною хворобою (ГХ). За даними MMAS, у 35\% чоловіків 40-70 років діагностовано помірну до тяжкої форму ЕД [6], що підтвердило зростання тяжкості ЕД із віком і наявністю коморбідних станів. Цілковиту імпотенцію відзначено у 28\% чоловіків із ЦД, тоді як у загальній популяції чоловіків iї виявлено лише в 9,6\% спостережень. Вважають, що ЕД розвивається в близько 40\% випадків серед чоловіків із ЦД і в до 30\% - серед чоловіків із ССЗ [5]. Тобто, ЕД асоційовано зі старінням чоловічого організму та коморбідними станами: ЦД2, артеріальною гіпертензією (АГ), вісцерально-абдомінальним ожирінням (ВО), CС3 [7]. Аналіз даних літератури засвідчив високу частоту ЕД серед чоловіків із ЦД2 типу і коморбідними станами, причому вона може бути передвісником розвитку СС3 у цій популяції високого ризику [1].

Встановлено, що на тлі ЦД ЕД розвивається на декілька років раніше, ніж у загальній популяції, та перебігає тяжче. У чоловіків із ЦД ризик розвитку ЕД у 3 рази вищий, ніж у загальній популяції [5]. Залежно від тяжкості та тривалості ЦД2, наявності коморбідних станів частота ЕД коливається від 20\% до 90\% [8-11]. Прогнозують зростання числа хворих на ЦД у США до 2050 р. до 29 млн, що буде супроводжуватися зростанням кількості чоловіків з ЕД [12]. Американською асоціацією андрологів проаналізовано дані 28 млн чоловіків, що були відібрані для множинного регресійного аналізу, когорту з ЕД (9 285000 чол.) і 1,5 млн осіб без ЕД і визначено, що ЕД є предиктором розвитку ЦД2 та нерідко може бути першим симптомом ЦД2 і виявляється на декілька місяців раніше, ніж маніфестують симптоми діабету.

До того ж вважають, що ЕД є високопревалентною в чоловіків із ЦД2 і раннім клінічним показником («сторожовим симптомом») у пацієнтів із СС $3[13,14]$. За результатами обстеження 422 чоловіків, хворих на ЦД, ЕД було діагностовано у 85,5\% випадків, причому вік і тривалість ЦД були вірогідними предикторами розвитку
ЕД. Тобто, частота ЕД значною мірою корелює із ССЗ, ЦД2 і метаболічним синдромом, що підтверджено в тривалих дослідженнях $[1,15,16]$. За даними проведених клінічних досліджень i ретроспективного аналізу, ЕД може фактично передувати появі цих станів у багатьох чоловіків [17, 18], що було також визнано консенсусною групою експертів Другого Прінстонського консенсусу з питань сексуальної дисфункції та кардіального ризику.

MMAS було також одним із перших досліджень, що засвідчили асоціацію між чинниками ризику ССЗ та ЕД [5], оскільки після ад’юнктування віку ЕД корелювала 3 наявністю захворювань серця, АГ, ЦД2, курінням, дисліпідемією. Встановлено, що ССЗ є джерелом значної захворюваності та смертності, незважаючи на успіхи в профілактиці, діагностиці та лікуванні [19]. Нові глобальні та регіональні прогнози смертності та тягаря хвороб із 2002 до 2030 року визначили, що IXC і цереброваскулярні захворювання були найчастішими причинами смерті у світі 2002 року та залишатимуться головними причинами смерті 2030 року [20]. Тому рання діагностика цих захворювань ще перед появою клінічних симптомів є важливою з огляду на можливість вчасного призначення лікування.

У розвитку ЕД і ССЗ беруть участь спільні патофізіологічні механізми, які часто співіснують [21]. Незалежні чинники ризику для ЕД і серцево-судинних захворювань є добре відомими - вік, куріння, ЦД, гіпертензія, дисліпідемія, депресія, ожиріння та малорухомий спосіб життя $[22,23]$. Показано, що одні й ті самі чинники ризику розвитку захворювань коронарних артерій є також чинниками ризику розвитку ЕД [24]. Проте незалежно від встановлених традиційних чинників ризику розвитку ССЗ, ЕД вірогідно асоціюється зі збільшенням випадків ССЗ. Системний огляд і метааналіз когортних досліджень (92757 пацієнтів) засвідчив, що в пацієнтів з ЕД порівняно з пацієнтами без ЕД підвищено ризик розвитку загальних СС3 на 44\%, інфаркту міокарда - на $62 \%$ і цереброваскулярних подій - на 39\% [25]. За даними обстеження 1067 чоловіків віком 40-70 років із ЦД2 і відсутністю СС3 на початку дослідження встановлено, що ЕД вірогідно асоціюється зі збільшенням випадків ССЗ [26].

Ступінь ЕД сильно корелює з тяжкістю СС3, і нещодавні дослідження припускають, що ЕД 
може розглядатися як предиктор їх маніфестації у хворих з асимптомними ССЗ [14, 16, 27]. Отримано переконливі докази, що ССЗ та ЕД мають спільну етіологію та патофізіологію, і найбільш поширеним й основним механізмом, що становить підгрунтя ССЗ та ЕД, є ендотеліальна дисфункція [13, 28]. Збільшення числа пацієнтів із чинниками ризику ССЗ відбувається паралельно із загальносвітовим зростанням поширеності ЕД [29-31]. Вважають, що як ендотеліальне захворювання ЕД дуже часто є показником органних та/або судинних ускладнень і погіршення основного захворювання.

Наразі вважають, що ЕД у більшості чоловіків є судинною патологією, підгрунтя якої становить ендотеліальна дисфункція [32-34]. Ендотеліальна дисфункція є одним із найбільш ранніх проявів атеросклеротичного захворювання судин і виявляється в пошкоджених судинах раніше, ніж зниження кровобігу, зумовлене атеросклеротичними бляшками [24]. ЕД часто передує ССЗ і часто присутня в чоловіків iз наявними СС3, і це наводить на думку, що чоловік з ЕД і відсутністю будь-яких симптомів ССЗ є пацієнтом із серцевою або судинною патологією доти, поки не підтверджено протилежне, а чоловік із наявним ССЗ має бути рутинно обстежений щодо стану його еректильної функції [35].

Клітини гладеньких м'язів судин релаксують і розширяються під дією цГМФ, який регулюється звільненням оксиду азоту в ендотелії у відповідь на такі стимули, як зростання вираженості стресу на тлі підвищеного кровобігу та стимуляції мускаринових рецепторів [32, 36]. Ендотеліальна дисфункція супроводжується порушенням продукції оксиду азоту, що запобігає розслабленню та розширенню судинної тканини, що вистилає артеріоли [32, 37]. Дослідження в 30 чоловіків з ЕД і відсутністю структурних і функціональних порушень судинного ложа, які становлять підгрунтя клінічно встановлених СС3, засвідчили, що в них було знижено пік швидкості систолічного кровобігу (28 м/c vs $>35$ м/с у контролі), зменшено показник вазодилатаціï brachial artery flow-mediated (1,3\% vs $2,4 \%)$ і вазодилататорну відповідь на приймання нітрогліцерину (13\% vs 18\%) [38]. Ці дослідження підтвердили наявність дефектів периферичних судин, асоційованих з ендотелій-залежною та ендотелій-незалежною вазодилатацією. Отже, дисфункція ендотелію є маркером захворювання периферичних судин перед їх клінічною діагностикою [39].

Перші повідомлення, що ЕД може бути маркером асимптомних випадків захворювання коронарнихартерій(ЗКА),з'явилися 2001 року[40,41]. У подальшому Ед було ідентифіковано як предиктор ЗКА у 2/3 випадків з інтервалом у часі 2-3 роки для IXC та інсульту $[42,43]$.

$\mathrm{У}$ ретроспективному аналізі даних обстеження 9457 чоловіків встановлено, що ЕД була сильним маркером майбутніх СС подій і асоціювалася з більшим показником ризику, ніж куріння, дисліпідемія або IM, у родинному анамнезі [44]. Обстежували чоловіків, в яких в анамнезі не було IM, хронічної серцевої недостатності, стенокардії, аритмії, інсульту. Дана популяція була більш здоровою, активною й освіченішою в плані розвитку ризику СС3, ніж загальна популяція. Випадок ЕД визначали як перше повідомлення про ЕД будь-якого ступеня. Для оцінки асоціації між ЕД і ССЗ використовували пропорційні ризики регресійної моделі. Встановлено вірогідний зв'язок між інцидентом ЕД i наступною стенокардією після коваріантного коригування, але ризик інсульту не був вірогідним. Інцидент ЕД було пов'язано зі скоригованим коефіцієнтом ризику 1,25 (95\% ДІ 1,02-1,53; $\mathrm{p}=0,04)$ для наступних серцево-судинних подій (IM, інсульт, стенокардія або хронічна серцева недостатність). Нескоригований ризик інциденту серцево-судинних подій у чоловіків без ЕД на початку дослідження становив 0,015 на людину в рік проти 0,024 на людину в рік для тих, у кого була ЕД. Отже, наявність ЕД надає унікальну можливість для первинної профілактики в усіх чоловіків з або без явних чинників ризику серцево-судинних подій і має спонукати до обстеження та втручання для виявлення серцево-судинних чинників ризику.

В іншому дослідженні ЕД передувала IM у 64\% пацієнтів [45]. Дослідження частоти ЕД у групі чоловіків 3 ангіографічно доведеним ЗКА (133 пацієнти) та 127 пацієнтів без ішемії засвідчили наявність ЕД у 33,8\% випадків серед перших і в 4,7\% - серед других [46]. Автори констатують, що ЕД жорстко незалежно асоційовано з ангіографічно доведеним ЗКА в чоловіків із ЦД2. ЕД спостерігали в пацієнтів із ЦД2 у 8 разів частіше, ніж у чоловіків із відсутністю безсимптомного ЗКА. 
Огляди

У ретроспективному дослідженні аналіз даних 12825 пацієнтів з ЕД і 12825 чоловіків без ЕД засвідчив, що в чоловіків з ЕД через 1 рік IM діагностувався у 2 рази частіше після корекції на вік, куріння, ожиріння, приймання серцевосудинних препаратів [47].

Проведені недавно дослідження припускають тісний зв'язок між ЕД та атеросклерозом, що дає можливість вважати ЕД клінічним маркером коронарних, периферичних і церебросудинних захворювань [48, 49].

Зв'язок між ЕД і ССЗ може бути зумовлений багатьма спільними чинниками. Частота ЕД була вищою серед чоловіків із ЦД2 й асимптомним, але ангіографічно доведеним ЗКА, ніж у чоловіків лише 3 діабетом. Наявність ЕД пов'зано $з$ 14,8-кратним збільшенням ризику розвитку IXC, і вона була найбільш ефективним предиктором серед інших традиційних чинників ризику СС3 [49]. В іншому дослідженні понад половину обстежених із ЦД2 з ангіографічними ознаками IXC мали симптоми ЕД перед розвитком симптомів стенокардії [50]. Ці знахідки підтримують ідею, що ЕД може бути сурогатним маркером майбутнього ЗКА, хоча потенційні дані відсутні. За оцінками показника ризику Framingham, приблизно у чверті чоловіків середнього віку розвивається ЗКА в межах 12 років [51]. У цьому дослідженні з медіаною спостереження 4,4 року китайських чоловіків із ЦД2 та ЕД встановлено показник подій ЗКА щорічно 20/1000 людино-років. Це свідчить про 1,6-кратно підвищений ризик порівняно з таким для чоловіків без ЕД. Важливо, що ризик асоціації між ЕД і новими подіями ЗКА залишався вірогідним після коригування на інші чинники. Крім того, жоден з обстежених не мав раніше СС3, і даний факт підтримує положення, що ЕД є раннім маркером IXC у чоловіків із ЦД2. Тому отримані результати доводять необхідність включення обстеження на ЕД у комплекс заходів з оцінки СС ризику [52]. Припускають, що мікроциркуляція в статевому члені може порушуватися на початку розвитку метаболічних і гемодинамічних порушень, таких як гіперглікемія, дисліпідемія, гіпертензія, оксидативний стрес тощо. Це призводить до ендотеліальної дисфункції та розвитку ЕД, яка характеризується затримкою в часі до досягнення максимальної ерекції, зниженням ригідності та здатності підтримувати ерекцію. У таких пацієнтів ана- логічні патологічні процеси можна очікувати і в інших ділянках циркуляції. Порушена ендотелій-залежна і незалежна вазодилатація присутня в пацієнтів із ЦД та ЕД і передує розвитку явного ЗКА $[28,53]$. Хоча незалежним предиктором нового початку хвороби коронарних судин $є$ приймання антигіпертензивних препаратів, ЕД залишається незалежним предиктором на підставі результатів Сох регресійного аналізу. Отримані результати переконливо свідчать, що ЕД є сурогатним маркером для майбутнього ЗКА. 3 огляду на це симптоми ЕД необхідно активно виявляти та використовувати для ідентифікації пацієнтів із високим ризиком серцевосудинних подій.

Припущення, що ЕД є незалежним проспективним маркером СС3, недавно було підтверджено результатами тривалого популяційного дослідження в когорті, яка включала 1248 чоловіків без СС 3, серед яких 22,8\% мали ослаблену та $8,7 \%$ - значно ослаблену еректильну ригідність [54]. Дані щодо серцево-судинних чинників ризику на базовому рівні було використано для розрахунку ризику Framingham: 0,14 i 0,18 відповідно vs 0,12 у чоловіків із нормальними. Результати показали, що в 7945 людино-років відбулося 58 серцево-судинних подій. Співвідношення ризику становило 1,6 (95\% ДІ 1,2-2,3) для зниження еректильної ригідності та 2,6 (95\% ДІ 1,3-5,2) для значного зменшення еректильної ригідності, а це свідчить, що наявність ЕД є сильним індикатором серцево-судинних подій незалежно від класичних чинників ризику.

Результати ретроспективного дослідження серед когорти з 12825 чоловіків з ЕД і периферичними судинними захворюваннями також дозволяють припустити, що ЕД може бути маркером для СС3 із ризиком ставати більш визначеним зі збільшенням віку [47].

Чоловіки із ЦД є схильними до розвитку серцево-судинних ускладнень. Асоціацію між ЕД i вперше виявленою IXC було документально підтверджено в недавньому дослідженні [55]. У проспективному аналізі великої когорти (2306) чоловіків, які не мали клінічних ознак СС3, зазначено, що у 26,7\% випадків була наявною ЕД на початку дослідження, і частота ЗКА була вищою, ніж серед чоловіків без ЕД (19,7 на 1000 людино-років, 95\% ДІ 14,3-25,2 vs 9,5 на 1000 людино-років, 95\% ДІ 7,4-11,7). Чоловіки, в яких розвивалося ЗКА, були старшими та мали 
більшу частоту ЕД і мікросудинних ускладнень. Автори постулюють, що присутність ЕД у чоловіків із ЦД2 без клінічно явного ССЗ є предиктором розвитку нових СС3 [55].

ЕД також сильно корелює з IXC. Обстежували 300 послідовних пацієнтів із гострим болем у грудній клітці та документально підтвердженою ангіографічно IXC за допомогою інтерв'ю для оцінки медичного та сексуального анамнезу. Результати показали, що 49\% пацієнтів з IXC також мали ЕД. Крім того, майже в 70\% випадків симптоми ЕД передували симптомам ЗКА [56].

Інше дослідження серед 40 пацієнтів з IXC показало вірогідну кореляцію між ЕД і числом коронарних судин, задіяних в ішемії. Пацієнти 3 хворобою 1 судини мали більше $(\mathrm{p}<0,04)$ і більш стійкі ерекції ( $<<0,007)$, ніж чоловіки із захворюванням 2 або 3 судин [57].

Попри вищезгадані кореляції між ЕД та IXC у пацієнтів з ЕД без клінічно виявленої IXC зрідка мають місце супутні симптоми ЗКА, тоді як пацієнти із ЗКА, як відомо, часто мають симптоми ЕД [14]. В одному з досліджень встановлено кореляцію високого ступеня ЕД із німою ішемією міокарда та IXC у чоловіків із неускладненим ЦД2. Цікаво, що, хоча поліморфізм аполіпопротеїну (а), куріння, мікроальбумінурія, ЛПВЩ-Х і ЛПНЩ-Х було значно пов'язано з безсимптомним ЗКА в цьому дослідженні, ЕД виявилася найбілыш ефективним предиктором скритого IM [49].

ЕД може передувати гострому коронарному синдрому [56], оскільки гіпотеза розривів асимптоматичних багатих ліпідами бляшок підтримує гіпотезу діаметра артерій та ролі ЕД як вікна можливостей для попередження наступних ССЗ подій, включаючи смерть.

Тестостеронова недостатність часто асоціюється із ЦД2, коморбідними захворюваннями та ЕД, що необхідно враховувати в обстеженні таких пацієнтів [58].

Кілька досліджень показали, що ЕД асоціюється з маркерами та медіаторами субклінічного запалення та ендотеліальної активації, підкреслюючи потенціал зв'язку ЕД/ССЗ, але не прояснюючи наявність ранньої хвороби бляшок [59]. Тоді стрес-тестування відіграє роль у встановленні серцево-судинної безпеки статевої активності, наприклад після IM або коронарної ангіопластики, субклінічна бляшка може не бути виявленою. Це, очевидно, важливо, оскільки ЕД є предиктором гострих коронарних синдромів і смерті від будь-яких причин, які в $60 \%$ випадків не є асоційованими 3 попередніми серцевими симптомами [25]. Тому оцінка субклінічних (>5\%) бляшок має велике значення, надто в молодих чоловіків із проміжним ризиком [60].

Отже, результати аналізу даних великої когорти чоловіків із ЦД2 переконливо свідчать, що ЕД є сурогатним маркером для майбутнього захворювання коронарних судин серця та периферичних, судин головного мозку, а також гіпертонії та ЦД, надто підкреслюючи ризик асоціації між ЕД і можливим початком розвитку ЗКА. ЕД може бути маркером ендотеліальної дисфункції.

Оскільки ЕД і ССЗ є явно пов'язаними, усі чоловіки з ЕД мають підлягати ретельному медичному обстеженню, включаючи кардіологічне. 3 точки зору серцево-судинних перспектив медичне обстеження має включати визначення AT, рівня глюкози натще, глікованого гемоглобіну, ліпідного профілю, обводу талії, тиреоїдної функції та тестостерону $[61,62]$. Симптоми ЕД необхідно активно виявляти 3 метою виділення групи ризику СС3 та ініціювати цілеспрямовані зміни способу життя для зниження ризиків. ЕД часто передує ССЗ і також нерідко присутня в чоловіків із діагностованими ССЗ, і це наводить на думку, що чоловіка з ЕД і відсутністю будь-яких симптомів ССЗ слід розглядати як пацієнта із серцевою або судинною патологією доти, поки не підтверджено протилежне, а чоловіка 3 наявним СС3 слід обов'язково опитувати про стан його еректильної функції. Скринінг і діагностика ЕД може мати суттєве значення для первинної профілактики, оскільки є простим, недорогим й альтернативним дослідженню біомаркерів серцево-судинних подій підходом. Наявність ЕД підвищує ризик розвитку серцево-судинних подій, передуючи діагностиці клінічно явних СС3 на 2-5 років і забезпечуючи вікно часу для більш ранньої діагностики та лікування, що може бути корисним з точки зору прогнозу. Крім того, ЕД є сильним прогностичним чинником смертності в чоловіків із ССЗ.

\section{Список використаної літератури}

1. Colson MH, Cuzin B, Faix A, Grellet L., Huyghes E. Current epidemiology of erectile dysfunction, an update. Sexologies. 2018 Jan; 27(1): e7-e13.

2. Rosen RC, Wing R, Schneider S, Gendrano N3rd. Epidemiology of erectile dysfunction: the role of medical comorbidities and lifestyle factors. Urol Clin North Am. 2005 Nov;32(4):403-17.

3. Walle B, Lebeta KR, Fita YP, Abdissa HL. Prevalence of erectile 


\section{Огляди}

dysfunction and associated factors among diabetic men attending the diabetic clinic at Felege Hiwot Referral Hospital, Bahir Dar, North West Ethiopia, 2016. BMC Res Notes. 2018 Feb 15;11(1):130-5.

4. Hsu B, Hirani V, Naganathan V, Blyth FM, Le Couteur DG, Seibel MJ, et al. Sexual function and mortality in older men: the concord health and ageing in men project. J Gerontol A Biol Sci Med Sci. 2017 Apr 1;72(4):520-7.

5. Feldman HA, Goldstein I, Hatzichristou DG, Krane RJ, McKinlay JB. Impotence and its medical and psychosocial correlates: results of the Massachusetts Male Aging Study. J Urol. 1994 Jan;151(1):54-61.

6. Shabsigh R. Obesity, metabolic syndrome and sexual dysfunction. J Sex Med. 2006; 3(Suppl 5):345-6.

7. Jackson G. Erectile dysfunction and cardiovascular disease. Arab J Urol. 2013 Sep; 11(3): 212-6.

8. Selvin E, Burnett AL, Platz EA. Prevalence and risk factors for erectile dysfunction in the US. Am J Med. 2007 Feb;120(2):151-7.

9. Sasaki H, Yamasaki H, Ogawa K, Nanjo K, Kawamori R, Iwamoto Y., et al. Prevalence and risk factors for erectile dysfunction in Japanese diabetics. Diabetes Res Clin Pract. 2005 Oct;70(1):81-9.

10. Bacon CG, Hu FB, Giovannucci E, Glasser DB, Mittleman MA, Rimm EB, et al. Association of type and duration of diabetes with erectile dysfunction in a large cohort of men. Diabetes Care. 2002 Aug;25(8):1458-63.

11. Лучицький $€ B$, Качура ОВ. Еректильна дисфункція у чоловіків, хворих на цукровий діабет. Ендокринологія. 2001;6(1):121-3. (Luchyts'kyy YeV, Kachura OV. Erectile dysfunction in men with diabetes mellitus. Endokrynolohiya. 2001;6(1):121-3).

12. Boyle JP, Honeycutt AA, Narayan KM, Hoerger TJ, Geiss LS, Chen H, Thompson TJ. Projection of diabetes burden through 2050: impact of changing demography and disease prevalence in the U.S. Diabetes Care. 2001 Nov;24(11):1936-40.

13. Wylie K. Erectile dysfunction. Adv Psychosom Med. 2008;29:33-49.

14. Montorsi P, Ravagnani PM, Galli S, Rotatori F, Briganti A Salonia A, et al. The artery size hypothesis: a macrovascular link between erectile dysfunction and coronary artery disease. Am J Cardiol. 2005 Dec 26;96(12B):19M-23M.

15. Giugliano F, Maiorino M, Bellastella G, Gicchino M, Giugliano D, Esposito K. Determinants of erectile dysfunction in type 2 diabetes. Int J Impot Res. 2010 May-Jun;22(3):204-9.

16. Jackson G, Rosen RC, Kloner RA, Kostis JB. The second Princeton consensus on sexual dysfunction and cardiac risk: new guidelines for sexual medicine. J Sex Med. 2006 Jan;3(1):28-36; discussion 36.

17. Billups KL, Bank AJ, Padma-Nathan H, Katz S, Williams R. Erectile dysfunction is a marker for cardiovascular disease: results of the minority health institute expert advisory panel. J Sex Med. 2005 Jan;2(1):40-50; discussion 50-2.

18. Thompson IM, Tangen CM, Goodman PJ, Probstfield JL, Moinpour CM, Coltman CA. Erectile dysfunction and subsequent cardiovascular disease. JAMA. 2005 Dec 21;294(23):2996-3002.

19. American Heart Association. Statistics Statistical Fact SheetPopulations 2007 update: International Cardiovascular Disease. http://www.americanheart.org/ downloadable/heart/.

20. Mathers CD, Loncar D. Projections of global mortality and burden of disease from 2002 to 2030. PLoS Med. 2006 Nov;3(11): e442.

21. Araujo AB, Hall SA, Ganz P, Chiu GR, Rosen RC, Kupelian V, et al. Does erectile dysfunction contribute to cardiovascular disease risk prediction beyond the Framingham Risk Score? J Am Coll Cardiol. 2010 Jan 26;55(4): 350-6.

22. Chobanian AV, Bakris GL, Black HR, Cushman WC, Green LA, Izzo JL Jr, et al. Seventh report of the Joint National Committee on Prevention, Detection, Evaluation, and Treatment of High Blood Pressure. Hypertension. 2003 Dec;42(6):1206-52.

23. Johannes CB, Araujo AB, Feldman HA, Derby CA, Kleinman $\mathrm{KP}$, McKinlay JB. Incidence of erectile dysfunction in men 40 to 69 years old: longitudinal results from the Massachusetts male aging study. J Urol. 2000 Feb;163(2):460-3.

24. Kloner RA. Erectile dysfunction and cardiovascular risk factors. In: Kloner R A (ed.). Contemporary cardilogy: heart disease and erectile dysfunction. Totova (NJ): Humana Press. 2004; 39-49.

25. Vlachopoulos CV, Terentes-Printzios DG, Ioakeimidis NK, Aznaouridis KA, Stefanadis CI. Prediction of cardiovascular events and all-cause mortality with erectile dysfunction. A systematic review and meta-analysis of cohort studies. Circ Cardiovasc Qua Outcomes. 2013 Jan 1;6(1):99-109.

26. Araujo AB, Hall SA, Ganz P, Chiu GR, Rosen RC, Kupelian V, et al Does erectile dysfunction contribute to cardiovascular disease risk prediction beyond the Framingham Risk Score? J Am Coll Cardiol. 2010 Jan 26 ; 55(4): 350-6.

27. El-Sakka AI. Association of risk factors and medical comorbidities with male sexual dysfunctions. J Sex Med. 2007 Nov;4(6):1691700 .

28. Kaiser DR, Billups K, Mason C, Wetterling R, Lundberg JL, Bank AJ. Impaired brachial artery endothelium-dependent and -independent vasodilation in men with erectile dysfunction and no other clinical cardiovascular disease. J Am Coll Cardiol. 2004 Jan $21 ; 43(2): 179-84$

29. Esposito K, Giugliano F, Martedì E, Feola G, Marfella R, D'Armiento M, Giugliano D. High proportions of erectile dysfunction in men with the metabolic syndrome. Diabetes Care. 2005 May;28(5):1201-3.

30. Fung MM, Bettencourt R, Barrett-Connor E. Heart disease risk factors predict erectile dysfunction 25 years later: the Rancho Bernardo Study. J Am Coll Cardiol. 2004 Apr 21;43(8):1405-11.

31. Ayta IA, McKinlay JB, Krane RJ. The likely worldwide increase in erectile dysfunction between 1995 and 2025 and some possible policy consequences. BJU Int. $1999 \mathrm{Jul} ; 84(1): 50-6$.

32. Miner MM, Kuritzky L. Erectile dysfunction: a sentinel marker for cardiovascular disease in primary care. Cleve Clin J Med. 2007 May;74 Suppl 3: S30-7.

33. Sullivan ME, Keoghane SR, Miller MA. Vascular risk factors and erectile dysfunction. BJU Int. 2001 Jun;87(9):838-45.

34. Solomon H, Man JW, Jackson G. Erectile dysfunction and the cardiovascular patient: endothelial dysfunction is the common denominator. Heart. 2003 Mar;89(3):251-3.

35. Böhm M, Baumhäkel M, Teo K, Sleight P, Probstfield J, Gao P, et al. Erectile dysfunction predicts cardiovascular events in high-risk patients receiving telmisartan, ramipril, or both: The ONgoing Telmisartan Alone and in combination with Ramipril Global Endpoint Trial/Telmisartan Randomized AssessmeNt Study in ACE i Ntolerant subjects with cardiovascular Disease (ONTARGET/TRANSCEND) Trials. Circulation. 2010 Mar 30;121(12):1439-46

36. Lue TF. Erectile dysfunction. N Engl J Med. 2000 Jun 15;342(24):1802-13.

37. De Angelis L, Marfella MA, Siniscalchi M, Marino L, Nappo F, Giugliano F, et al. Erectile and endothelial dysfunction in type II diabetes: apossiblelink. Diabetologia. 2001 Diabetologia. Sep;44(9):1155-60.

38. KaiserD.K., BillupsK., MasonC. etal. Impaired brachial artery endothelium dependent and independent vasodilatation in men with erectile dysfunction and no other clinical cardiovascular disease. J. Am.Coll.Cardiol. 2004. - Vol.43. - P. 179-84.

39. Kloner RA. Erectile dysfunction in the cardiac patient. Compr Ther. 2004 Spring;30(1):50-4. Kolodny L. Erectile dysfunction and vascular disease: what is the connection? Postgrad Med. 2003 Oct;114(4):30-4, 39-40.

40. O'Kane PD, Jackson G. Erectile dysfunction: is there silent obstructive coronary disease? Int J Clin Pract. 2001 Apr;55(3):219-20.

41. Kirby M, Jackson G, Betteridge J, Friedli K. Is erectile dysfunction a marker for cardiovascular disease? Int J Clin Pract. 2001 Nov;55(9):614-8

42. Inman BA, Sauver JL, Jacobson DJ, McGree ME, Nehra A, Lieber $\mathrm{MM}$, et al. A population-based, longitudinal study of erectile dysfunction and future coronary artery disease. Mayo Clin Proc. 2009 Feb;84(2):108-13.

43. Hodges LD, Kirby M, Solanki J, O'Donnell J, Brodie DA. The temporal relationship between erectile dysfunction and cardiovascular disease. Int J Clin Pract 2007;61:2019-25.

44. Thompson IM, Tangen CM, Goodman PJ, Probstfield JL, Moinpour CM, Coltman CA. Erectile dysfunction and subsequent cardiovascular disease. JAMA. 2005;294(23):2996-3002.

45. Billups KL. Endothelial dysfunction as common link between erectile dysfunction and cardiovascular disease. Curr Sex Health Reports. 2004 Dec;1(4):137-41.

46. Gazzaruso C, Giordanetti S, De Amici E, Bertone G, Falcone C Geroldi D, et al. Relationship between erectile dysfunction and 
silent myocardial ischemia in apparently uncomplicated type 2 diabetic patients. Circulat. 2004;110 (1):22-6.

47. Blumentals WA, Gomez-Caminero A, Joo S, Vannappagari V. Should erectile dysfunction be considered as a marker for acute myocardial infarction? Results from a retrospective cohort study. Int J Impot Res. 2004; 16:350-3.

48. Fung MM, Bettencourt R, Barrett-Connor E. Heart disease risk factors predict erectile dysfunction 25 years later: the Rancho Bernardo Study. J Am Coll Cardiol. 2004 Apr;43(8):1405-11.

49. Gazzaruso C, Giordanetti S, De Amici E, Bertone G, Falcone C Geroldi D, et al. Relationship between erectile dysfunction and silent myocardial ischemia in apparently uncomplicated type 2 diabetic patients. Circulation. 2004 Jul 6;110(1):22-6.

50. Solomon H, Man JW, Wierzbicki AS, Jackson G. Relation of erectile dysfunction to angiographi coronary artery disease. Am J Cardiol. 2003 Jan; 91(2):230-1.

51. Speel TG, van Langen H, Meuleman EJH. The risk of coronary heart disease in men with erectile dysfunction. J Eur Urol. 2003 Sep;44(3):366-71

52. Rydén L, Standl E, Bartnik M, Van den Berghe G, Betteridge J, de Boer MJ, et al. Guidelines on diabetes, pre-diabetes, and cardiovascular diseases: executive summary. TheTask Force on Diabetes and Cardiovascular Diseases of the European Society of Cardiology (ESC) and of the European Association for the Study of Diabetes (EASD). Eur Heart J. 2007 Jan;28(1):88-136.

53. Yavuzgil O, Altay B, Zoghi M, Gürgün C, Kayikçioğlu M, Kültürsay $H$. Endothelial function in patients with vasculo genicerectile dysfunction. Int J Cardiol. 2005;103 (1):19-26.

54. Schouten BW, Bohnen AM, Bosch JL, Bernsen RM, Deckers JW, Dohle GR, Thomas S. Erectile dysfunction prospectively associated with cardiovascular disease in the Dutch general population: results from the Krimpen Study. Int J Inpot Res. 2008 Jun-Feb;20(1):92-9.

55. Ma RC, So WY, Yang X, Yu LW, Kong AP, Ko GT, et al. Erectile dysfunction predicts coronary heart disease in type 2 diabetes. J Am Coll Cardiol. 2008 May;51(21):2045-50.

56. Montorsi F, Briganti A, Salonia A, Rigatti P, Margonato A Macchi A, et al. Erectile dysfunction prevalence, time of onset and association with risk factors in 300 consecutive patients with acute chest pain and angiographically documented coronary artery disease. Eur Urol. 2003 Sep;44(3):360-4.

57. Greenstein A, Chen J, Miller H, Matzkin H, Villa Y, Braf Z. Does severity of ischemic coronary disease correlate with erectile function? Int J Impot Res. 1997 Sep;9(3):123-6.

58. Jackson G. Testosterone de ciency syndrome (TDS) and the heart. Eur Heart J. 2010 Jun;31(12):1436-7.

59. Vlachopoulos C, Aznaouridis K, Ioakeimidis N, Rokkas K Vasiliadou C, Alexopoulos N, et al. Unfavourable endothelial and inflammatory state in erectile dysfunction patients with or without coronary artery disease. Eur Heart J. 2006 Nov; 27(22):2640-8.

60. Miner M, Seftel AD, Nehra A, Ganz P, Kloner RA, Montorsi P, et al Prognostic utility of erectile dysfunction for cardiovascular disease in younger men and those with diabetes. Am Heart J. 2012 Jul; 164(1):21-8

61. Nehra A, Jackson G, Miner M, Billups KL, Burnett AL, Buvat J, et al. Consensus recommendations for the management of erectile dysfunction and cardiovascular disease. Mayo Clin Proc. 2012 Aug;87(8):766-78.
62. Jackson G, Boon N, Eardley I, Kirby M, Dean J, Hackett G, et al. Erectile dysfunction and coronary artery disease prediction: evidence-based guidance and consensus. Int J Clin Pract. 2010 Jun;64(7):848-57.

(Надійшла до редакції 15.02.2019р.)

Эректильная дисфункция как предиктор риска развития сердечно-сосудистых заболеваний у мужчин с сахарным диабетом 2-го типа

\section{Н.Д. Тронько, Е.В. Лучицкий, В.Е. Лучицкий, Л.К. Соколова, А.Г. Зубкова, В.М. Рыбальченко, И.И. Складанная, Ю.Б. Бельчина}

ГУ «Институт эндокринологии и обмена веществ им. В.П. Комиссаренко НАМН Украины»

Резюме. В обзоре проанализирована роль эректильной дис функции (ЭД) у мужчин, больных сахарным диабетом 2-го типа, как одного из ранних маркеров развития сердечно-сосудистых заболеваний (СС3). Освещены современные взгляды на нарушение функции эндотелия как общего субстрата, который лежит в основе развития как ЭД, так и ССЗ.

Ключевые слова: эректильная дисфункция, сердечно-сосудистые заболевания, мужчина, сахарный диабет 2-го типа.

\section{Erectile dysfunction as a predictor of the risk of developing cardiovascular disease in men with type 2 diabetes mellitus}

\section{M.D. Tronko, Ye.V. Luchytsksy, V.Ye. Luchytsksy, L.K. Sokolova, G.A. Zubkova, V.M. Rybalchenko, I.I. Skladanna, Yu.B. Belchina \\ SI «V.P. Komisarenko Institute of Endocrinology and Metabolism, NAMS of Ukraine»}

Abstract. The review analyzed the role of erectile dysfunction (ED) in men who have type 2 diabetes mellitus as one of the early markers of cardiovascular disease (CVD). The contemporary views were discussed on endothelial function disorders, as common substrate underlying in the development of both ED and CVD.

Keywords: erectile dysfunction, cardiovascular diseases, man, type 2 diabetes mellitus. 